\title{
Mateusz Grodecki
}

Uniwersytet Warszawski

\section{Nowi aktywiści. Polski ruch „,socios” jako nowa forma relacji kibiców z klubem}

\section{DOI: http://dx.doi.org/10.18778/1733-8069.14.2.02}

Abstrakt Artykuł skupia się na problematyce kibicowskiego ruchu „,socios" w Polsce. Jego celem jest 1) opisanie socjogenezy tego ruchu w Polsce, 2) charakterystyka relacji pomiędzy kibicami w ramach poszczególnych stowarzyszeń „socios” oraz 3) relacji tych organizacji ze swoimi klubami. Taki porządek umożliwi następnie analizę potencjału ruchu „socios” do zwiększenia inkluzywności w relacjach klubów z kibicami i dzięki temu do tworzenia się „łączącego" kapitału społecznego zarówno pomiędzy kibicami danego klubu, jak i kibicami i klubami. Podstawą empiryczną przedstawianego artykułu jest studium przypadku dwóch stowarzyszeń typu „,socios” w Polsce: Stowarzyszenia „Socios Górnik” - działającego przy klubie Górnik Zabrze oraz Stowarzyszenia „Socios Stomil" - wspierającego klub Stomil Olsztyn. Wyniki badania wskazują na responsywny charakter ruchu spowodowany zagrożeniem poczucia „własności kulturowej” klubu. Co więcej, jest on w dużej mierze inspirowany przez fanów niezwiązanych do tej pory ze zorganizowanym środowiskiem kibiców piłkarskich obu klubów - nazwanych w pracy „nowymi aktywistami”. Relacje w ramach organizacji regulowane są prawnie, jednak w ramach wspólnych działań wytwarzają się również mniej formalne relacje, a w konsekwencji zaufanie między liderami stowarzyszeń. Analizowane przypadki różnią się również efektywnością działań na rzecz zwiększenia inkluzywności klubu w relacjach z kibicami. Badanie wskazuje, że głównymi przyczynami tych różnic są: odmiennie definiowana przez obie organizacje inkluzywność, upolitycznienie konfliktu z klubem oraz zależność finansowa od właściciela - miasta.

Słowa kluczowe socjologia sportu, kibice, kapitał społeczny, społeczeństwo obywatelskie

Mateusz Grodecki, doktor socjologii. W pracy badawczej zajmuje się socjologią sportu, ze szczególnym uwzględnieniem szeroko pojętego zjawiska kibicowania. Autor i współautor artykułów naukowych publikowanych w kraju i zagranicą oraz licznych opracowań i raportów (m.in. dla CBOS).

\section{Adres kontaktowy:}

Instytut Socjologii

Uniwersytet Warszawski

ul. Karowa 18

00-927 Warszawa

e-mail: grodecki.mateusz@gmail.com
Dojawienie się wolnorynkowych reguł w futbo1 lu diametralnie odmieniło obraz tej dyscypliny sportu. Jej dotychczasowy, masowy i robotniczy charakter ukształtowany na przełomie XIX i XX wieku przez procesy urbanizacji i industrializacji został dynamicznie przekształcony przez neoliberalną logikę rynku (zob. Numerato 2015) w przeznaczony do konsumowania produkt dla globalnej publiczności (Williams 2006; 2007). Nowy porządek przemodelował także obraz piłkarskich trybun, zastępując tradycyjnie obecnych tam mężczyzn z klasy robotniczej fanami wywodzącymi się z wyższych klas (ang. gentrification) oraz przyczynił się do pojawienia się na stadionach całych rodzin (ang. familization), a przez to i feminizacji futbolowej publiczności (Martin 2007: 638). Przede wszystkim jednak rynkowa logika futbolu zredefiniowała relacje na linii kibice-klub. Oryginalnie cechujący się ideą mutualizmu (zob. Martin 2007; Antonowicz, Kossakowski, Szlendak 2015) związek klubu z lokalną wspólnotą przybrał formę relacji rynkowej, w której kibice stali się dla swoich klubów wiernymi klientami (Martin 2007; Antonowicz, Kossakowski, Szlendak 2015).

Nowa rzeczywistość spotkała się z wieloma formami kontestacji ze strony tradycyjnych fanów. Kibice protestowali przeciwko modernizacji stadionów (Nash 2000) czy drastycznym podwyżkom cen biletów w angielskiej Premiership (Williams 2007). Opozycja wobec zmian widoczna była również na poziomie lokalnym, gdzie motorem konfliktu stali się między innymi nowi właściciele klubów, którym zarzucano nastawienie na zysk kosztem tradycji. Takie ruchy obecne były zarówno w Polsce (zob. Chwedoruk 2015), jak i na świecie (zob. Guschwan 2007; Cleland 2010). Sprzeciw wobec urynkowienia futbolu kosztem lokalnych tradycji przybrał w konsekwencji postać globalnego, wielowymiarowego i przez to również niespójnego ruchu sprzeciwu „Against Modern Football” (zob. Numerato 2015).

Na redefinicję roli kibica wpłynęły także związane z utowarowieniem futbolu problemy klubów piłkarskich. Diametralnie wzrosła rola kapitału finansowego, stawiając ten zasób w roli koniecznego, ale niewystarczającego czynnika w nowoczesnym sporcie. Dopiero wysoki budżet umożliwia bowiem rywalizację na odpowiednim poziomie, nie gwarantując przy tym sukcesów sportowych. Taki mechanizm tworzy tym samym zamknięte koło - do rywalizacji niezbędny jest kapitał, który z kolei można uzyskać przez sukcesy (Antonowicz i in. 2015). Pęd za wynikiem sportowym i finansowym okazał się zgubny dla niektórych klubów. Niektóre z nich zaczęły się zadłużać, chcąc doścignąc uciekający w coraz szybszym tempie peleton, co w przypadku braku sukcesów sportowych, a związku z tym i braku zastrzyku gotówki, niejednokrotnie kończyło się ich bankructwami.

W Anglii, w odpowiedzi na problemy finansowe klubów, powstały kibicowskie "trusty” (ang. Supporters Trusts), których głównym celem była obywatelska kontrola zarządzania klubem, a przez to uzyskanie większej inkluzywności ze strony klubów w relacjach z fanami (Martin 2007; Millward 2012; Williams 2012). Ruchy te cechują się responsywnym charakterem, bowiem większość z nich została utworzona lub zaczęła aktywnie działać w efekcie tragicznej sytuacji finansowej swoich klubów (Lomax 2000; Martin 2007; Cleland 2010; Cleland, Dixon 2014). Instytucja „trustów" zaczęła być również wykorzystywana 
przez brytyjskich kibiców jako zalegitymizowane narzędzie kontestacji zmian właścicielskich (Brown 2007; Millward 2012; Williams 2012).

W Polsce urynkowienie futbolu wiązało się przede wszystkim ze zmianą systemową. W epoce socjalizmu kluby piłkarskie funkcjonowały pod patronatem zakładów przemysłowych lub instytucji państwowych (służby, wojsko itp.). Nowa rzeczywistość wymusiła na klubach piłkarskich adaptację do rynkowej logiki. Nie wszystkie kluby potrafiły się jednak w nowych warunkach gospodarczych odnaleźć. Niektóre z nich w związku z problemami finansowymi ogłaszały upadłość. Inne natomiast padały ofiarą ekscentrycznych właścicieli albo stawały się częścią większych inwestycji, po czym wyeksploatowane zostawały bez wsparcia finansowego. W Polsce, w przeciwieństwie jednak do Anglii, kibice nie angażowali się $\mathrm{w}$ sformalizowane ruchy sprzeciwu. W takich sytuacjach częściej decydowali się na oddolną odbudowę swoich klubów od podstaw (Dudała 2004; Chwedoruk 2015; Kossakowski 2017a).

W ostatnich kilku latach pojawiła się w Polsce nowa forma ruchu kibicowskiego. Grupy kibiców Górnika Zabrze i Stomilu Olsztyn zorganizowały się w stowarzyszenia mające na celu wsparcie finansowe (choć nie tylko) swoich klubów. Ten ruch przybrał w Polsce nazwę „,socios", odwołując się do hiszpańskiej tradycji demokratycznego zawiadywania klubami przez kibiców - „partnerów” (zob. Brown, Walsh 2000: 93-95; Giulianotti 2002: 26).

Prezentowany artykuł skupia się na problematyce tego ruchu kibicowskiego. Jego celem jest 1) opisanie socjogenezy ruchu „socios” w Polsce, 2) charaktery- styka relacji pomiędzy kibicami $\mathrm{w}$ ramach poszczególnych stowarzyszeń „socios” oraz 3) relacji tych organizacji ze swoimi klubami. Taki porządek umożliwi następnie analizę potencjału ruchu "socios" do zwiększenia inkluzywności ${ }^{1}$ w relacjach klubów z kibicami i dzięki temu do tworzenia się "łączącego" kapitału społecznego (zob. Putnam 2008) zarówno pomiędzy kibicami danego klubu, jak i kibicami i klubami. Artykuł ma charakter eksploracyjny i opiera się na jakościowej analizie studium przypadku dwóch istniejących stowarzyszeń „,socios”.

Tekst rozpoczyna się od omówienia dostępnej literatury z zakresu badań nad aktywizmem kibiców piłkarskich. Dalej opisana zostaje metodologia badania. Następnie, zgodnie z przedstawioną wyżej logiką, prezentowana jest analiza obu przypadków. Na końcu znajduje się dyskusja nad uzyskanymi rezultatami oraz konkluzje.

\section{Kibicowscy aktywiści}

Problematyka oddolnego aktywizmu kibiców piłkarskich, mimo że aktualna i podejmowana na kilku płaszczyznach, wciąż pozostaje stosunkowo słabo zagospodarowana $w$ naukach społecznych. W Polskim dyskursie naukowym analizowano aktywność obywatelską czy szerzej - pozastadionową w ramach stowarzyszeń kibiców (zob. Burski 2013; Grodecki 2015) i programu „Kibice Razem” (Kossakowski 2017b) oraz eksplorowano działania fanów na rzecz odbudowy upadłych klubów (zob. Kossa-

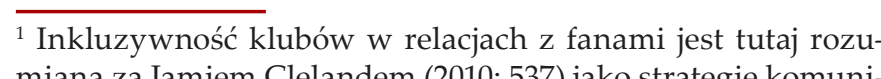
miana za Jamiem Clelandem (2010: 537) jako strategie komunikacji i interakcji z władzami klubowymi, które mają wpływa
na podejmowane przez klub decyzje. kowski 2017a). Wymienione obszary aktywności, $\mathrm{w}$ przeciwieństwie do przedstawianego tu ruchu "socios", dotyczą jednak głównie zorganizowanego środowiska kibiców - ukształtowanego wcześniej przez wielowymiarową rywalizację z innymi grupami fanów (zob. Grodecki 2017).

W międzynarodowym obiegu najwięcej uwagi analitycznej poświęcono natomiast brytyjskim Supporters Trusts. Początek działalności tych organizacji datuje się na 1985 rok. Niedługo po tragedii na Heysel powstaje bowiem Football Supporters Association, stając się, zdaniem Jamie Clelanda i Kevina Dixona (2015: 543), pierwowzorem dla bardziej niezależnych i lokalnych inicjatyw. Te zaczynają kształtować się z kolei w latach dziewięćdziesiątych ubiegłego stulecia. Ich geneza wiążę się bardzo mocno z utowarowieniem futbolu i coraz większą ekskluzywnością w relacjach klubów ze swoimi fanami. Okres lat dziewięćdziesiątych nie jest przypadkowym, bowiem w 1992 roku zostaje powołana Premiership. Jak pisze John Williams (2006: 100 [tłum. własne]): „Była to pierwsza czołowa liga w Europie, która została utworzona przez i dla telewizji, w tym przypadku przez nowopowstałą stację telewizyjną BSkyB kontrolowaną przez Ruperta Murdocha". Przekształcenie ligi piłkarskiej w produkt medialny o globalnej skali doprowadziło do pojawienia się w futbolu niewyobrażalnych do tej pory środków finansowych, które koncentrowały się jednak głównie w najlepszych i największych klubach (Williams 2006), umacniając jednocześnie korporacyjny stosunek tych klubów do swoich kibiców.

W 1992 roku powstaje również pierwszy lokalny Supporters Trust, założony przez kibiców zadłużone- go po brzegi Northampton Town, którego głównym celem była pomoc finansowa klubowi (Lomax 2000). Jak zauważa Cleland (2010), w historii angielskiego futbolu zdarzały się wcześniej przypadki wsparcia finansowego klubów przez swoich fanów, którzy przez uczestnictwo $\mathrm{w}$ meczach byli również jednymi z ich głównych „udziałowców”. To, co jednak wyróżniało NTFCST (Northapton Town FC Supporters Trust), to postulat o formalne zwiększanie roli kibiców w zarządzaniu klubem w zamian za zebrane środki finansowe (Lomax 2000).

W 2000 roku, za sprawą rządu Tonego Blaira, powstaje Supporters Direct. Organizacja mająca być, jak zauważa Paul Martin (2007: 642 [tłum. własne]), ,jednostką do zadań specjalnych". Celem tej organizacji miała być przede wszystkim pomoc kibicom w tworzeniu "trustów” na poziomie lokalnym i dzięki temu przekształcanie relacji klubów z kibicami w bardziej partycypacyjne. Ta odgórna inicjatywa, oparta na idei mutualizmu, miała „zachęcić i ułatwić kombinacje udziałów pojedynczych kibiców w ich klubie, licząc, że doprowadzi to do nabycia przez grupy kibiców możliwości uczestniczenia w strukturach decyzyjnych klubów" (Martin 2007: 643 [tłum. własne]). W konsekwencji tych działań liczba "trustów” zwiększyła się z 17 istniejących w 2001 roku do 63 w 2004 (Martin 2007: 643). W 2014 roku działały już natomiast 203 organizacje tego typu, z czego 75 miało swojego reprezentanta $\mathrm{W}$ zarządzie klubu (Garcia, Welford 2015: 520). Działalność „,trustów”, a zwłaszcza ich efektywność w zwiększaniu inkluzywności na rzecz udziału fanów w zarządzaniu klubem ogranicza się jednak głównie do niższych lig (Martin 2007). Większe, odnoszące sukcesy kluby dysponują bowiem ogrom- 
nymi budżetami i tym samym nie są zmuszone do korzystania z pomocy finansowej swoich fanów. Wyższe budżety klubów zwiększają również ich wartość rynkową. W rezultacie wykupienie czynnego głosu w takiej spółce wymaga niebagatelnych kwot - dużo większych niż kibice są w stanie zgromadzić poprzez zbiórki (Cleland, Dixon 2015: 543). Co więcej, najczęściej „trusty” mają możliwość wejścia do zarządu klubu dopiero w obliczu dużych kryzysów finansowych (Kennedy 2012), a do tego są traktowane przez zarządzających klubami jako ostatnia opcja na „wsparcie finansowe” (Garcia, Welford 2015: 521)

Powyższe słowa doskonale ilustrują przykłady „trustów" powstałych jako forma kontestacji korporacyjnych właścicieli topowych angielskich klubów, jak Manchester United (Brown 2007), FC Liverpool (Millward 2012; Williams 2012) czy Newcastle United (Cleland, Dixon 2015), które były bezradne w walce z korporacyjnymi aktorami. Opierając się na logice rynku - wykupienia głosu w zarządzie klubu, który miał zwiększyć inkluzywność klubu wobec stanowiska kibiców - nie były w stanie zebrać wystarczających kwot, konkurujących z „korporacyjnymi” finansami. Co więcej, największe kluby operują na globalnym rynku mediowym i posiadają fanów na całym świecie. Tym samym mogą sobie pozwolić na ekskluzywne podejście wobec niezadowolonej mniejszości, nie ponosząc przy tym żadnych konsekwencji finansowych - na miejsce niezadowolonych fanów są inni chętni (Cleland 2010). Dlatego też w mniejszych klubach, nieodnoszących sukcesów i przez to $\mathrm{w}$ dużo większym stopniu uzależnionych od lokalnego rynku, istnieją większe szanse na, po pierwsze, inkluzywne relacje klubu z kibicami (przez mniejszą bazę potencjalnych fanów i przez to brak alternatyw), a po drugie, na wykupienie przez kibiców głosu (dużo niższa wartość ich akcji).

Przedstawione analizy uwidaczniają zatem pewne, charakterystyczne cechy omawianych ruchów kibicowskich: 1) ich responsywny charakter, bowiem "trusty" są odpowiedzią kibiców na finansowe i właścicielskie perypetie swojego klubu, 2) działania nakierowane na zwiększenie inkluzywności w relacjach klubu ze swoimi fanami, 3) skuteczność działania tych ruchów tylko w klubach pozostajacych lokalnymi markami, przez co funkcjonujących w pozakorporacyjnej, dostępnej dla fanów rzeczywistości finansowej.

Czwartym czynnikiem, podkreślanym $\mathrm{w}$ literaturze przedmiotu, są również szersze przemiany brytyjskiego społeczeństwa. Zmiana jego charakteru z industrialnego na bardziej usługowy przyczyniła się do zwiększenia liczebności i roli klasy średniej i tym samym do redefinicji tradycyjnego związku klubów z klasą robotniczą. Przemiana ta miała doprowadzić do wyłonienia się nowych kategorii kibiców, w tym "aktywnych fanów”, których zaangażowanie przejawiało się zarówno $\mathrm{w}$ ich prosumenckim charakterze relacji $\mathrm{z}$ klubem (poprzez redagowanie fanzinów, artykułów i nieoficjalnych stron poświęconych klubom) oraz w tworzeniu zaangażowanych stowarzyszeń kibiców (Cleland 2010). Geneza "trustów” jest zatem mocno zakorzenienia $\mathrm{w}$ szerszych przemianach struktury społecznej, które zredefiniowały tradycyjne relacje kibiców z klubem i w efekcie których wyłoniły się nowe kategorie kibiców, w tym kibiców „aktywnych".
Nieco szerszej perspektywy dotyczącej charakterystyki tej kategorii fanów dostarcza praca Petera MilIwarda, analizującego lobbujące za zmianą właścicieli klubu Liverpool FC stowarzyszenie "Spirit of Shankly". Millward (2012: 4) zauważył, że ruch ten tworzony był głównie przez „tradycyjnych" fanów (zob. supporter w Giulianotti 2002; zob. „kibice industrialni" w Antonowicz i in. 2015), natomiast zarząd organizacji oraz jej rzecznicy wywodzili się z klasy kreatywnej i profesjonalnej. Wskazuje również, że za motywacją tych przedsięwzięć stoi poczucie „własności kulturowej” klubu, która zostaje zagrożona przez „bezosobowy charakter futbolu w mocno skomercjalizowanych czasach" (Millward 2012: 6 [tłum. własne]). Millward (2012: 9) podkreśla także rolę Internetu jako skutecznego narzędzia komunikacji oraz narzędzia umożliwiającego stopniowe włączanie fanów przez dołączanie do różnych wydarzeń w mediach społecznościowych.

Socjogeneza angielskich „trustów” jest ważna dla analizowanego tu zjawiska z co najmniej trzech powodów. Po pierwsze, ze względu na podobny kontekst przemian - „urynkowienia” dominującego porządku społecznego, jak i piłki nożnej w szczególności - które odbywa się w Polsce jednak z pewnym opóźnieniem, stwarzając w kontekście analizowanego problemu specyficzne „laboratorium społeczne" (zob. Nosal 2015). Po drugie, sama geneza i charakterystyka polskiego ruchu "socios" jest zbliżona (ale nie tożsama) do angielskich "trustów". Jest to związane ze wskazanymi przemianami społecznymi i w przypadku Polski z istniejącymi już zachodnimi wzorcami kontestacji tych przemian. Po trzecie w końcu, przez brak opracowań analizowanego problemu w rodzimym dyskursie naukowym nakazuje szukać ram teoretycznych w obiegu międzynarodowym, w którym problematyka aktywizmu kibiców futbolowych zdominowana jest przez opracowania pochodzące z kontekstu brytyjskiego.

W analizach aktywizmu kibicowskiego w Europie często wykorzystywano teorie ruchów społecznych (zob. Blumer 1951; Touraine 1981; Castells 1983). Alberto Testa i Gary Armstrong (2010) omawiali $\mathrm{w}$ tym kontekście procesy polityzacji/depolityzacji włoskich grup ultras, Rafał Chwedoruk (2015) studiował protesty kibiców w Polsce, a Peter Millward i George Poulton (2014) rekonstruowali genezę klubu FC United, opierając się na tradycji teoretycznej Herberta Blumera (1951). Koncepcja Blumera wydaje się szczególnie ciekawa, ponieważ oferuje odpowiednie narzędzia analityczne umożliwiające kategoryzację danego ruchu społecznego przez pryzmat jego celów i metod działania, pozwalając jednocześnie na usytuowanie przedstawianej tu problematyki w szerszym kontekście teoretycznym.

Blumer (1951: 99 [tłum. własne]) definiuje ruchy społeczne jako „kolektywne przedsięwzięcia, które dążą do ustanowienia nowego porządku. Swoje źródła odnajdują w okolicznościach niepokoju, a siłę napędową czerpią z jednej strony z niezadowolenia $\mathrm{z}$ istniejącego porządku, a z drugiej strony z życzeń i nadziei na nowy system". W swojej pracy wyróżnił trzy typy ruchów społecznych: ogólne, ekspresywne oraz specyficzne. Ruchy ogólne (ang. general) mają być wynikiem niedopasowania instytucji do kultury. Stopniowa zmiana w kulturze tworzy nowe oczekiwania, które nie będąc $\mathrm{w}$ stanie być skonsumowanymi przez istniejące 
instytucje, stwarzają podatny grunt do powstania ogólnego ruchu społecznego. Ekspresywne (ang. expressive) ruchy to takie, których celem nie jest zmiana instytucjonalnego porządku społecznego. Są to raczej inicjatywy skupione na budowaniu wewnętrznej wartości kulturowej. Do takich ruchów zaliczają się ruchy religijne, które definiują swoich wiernych jako wybranych. Ruchy specyficzne (ang. specific) Blumer podzielił na ruchy reformatorskie oraz ruchy rewolucyjne. Te pierwsze skupiają się na zmianie jakiegoś fragmentu obowiązującego porząqku. Poruszając się $\mathrm{w}$ ramach obowiązujących reguł oraz wykorzystując do tego istniejące instytucje, dążą przede wszystkim do przekonania opinii publicznej do swoich celów. Celem ruchów rewolucyjnych jest natomiast holistyczna zmiana. Nie przywiązują wagi do istniejących instytucji i operują w "podziemiu”. Blumer (1951: 211-216) podkreślał, że ruchy reformatorskie przez swój zalegitymizowany charakter starają się uzyskać poparcie wśród klasy średniej, natomiast ruchy rewolucyjne skupiają się na pozyskaniu członków wśród „wyzyskiwanej” klasy, przez co rekrutują głównie przedstawicieli klas niższych.

\section{Metodologia}

Podstawą empiryczną przedstawianego artykułu jest studium przypadku skupiające się na aktywności dwóch stowarzyszeń typu „socios” w Polsce: Stowarzyszenia "Socios Górnik” - działającego przy klubie Górnik Zabrze oraz Stowarzyszenia „Socios Stomil” - wspierającego klub Stomil Olsztyn. W połowie 2017 roku były to jedyne stowarzyszenia bezpośrednio odwołujące się oraz identyfikujące się z przekształconą przez polski kontekst ideą „,socios”2 ${ }^{\prime 2}$ Ideę tę opisać można jako pewną oddolną interwencję kibiców, mającą na celu 1) regularne wsparcie finansowe klubu przez mobilizacje szerszej zbiorowości fanów oraz 2) pewne wsparcie organizacyjne klubu, które może być jednak różnie interpretowane (od udziału we władzach, po działania marketingowe - o czym dalej).

Taki model doboru przypadków (przez autodefinicję) umożliwia pewną dystynkcję pomiędzy dwiema ogólnymi kategoriami stowarzyszeń kibicowskich funkcjonujących w polskiej rzeczywistości: tych definiujących siebie jako „ramię klubu” - jak "socios” (Górnik Zabrze C, badanie własne) oraz tych działających dla środowiska kibiców. Definiowanie ruchu przez pryzmat jego celów oraz przez świadomość działania $w$ pewnym modelu organizacyjnym jest tutaj kluczowe. Istnieją bowiem organizacje kibicowskie, które przez to, że prowadzą działalność na rzecz klubu - również w oparciu o regularne składki swoich członków - mogłyby zostać określone przez wymienione wskaźniki jako organizacje typu „socios”. Takim przy padkiem jest na przykład OSK „Tylko Widzew". Z wywiadów przeprowadzonych z liderami tej organizacji wynikało jednak, że nie identyfikują się oni z ruchem „,socios” oraz że określają swoje stowarzyszenie jako działające głównie dla szeroko pojętego środowiska kibiców tego klubu.

W ramach studium przypadku wykorzystano analizę danych zastanych (strony internetowe sto-

${ }^{2}$ Natomiast nie były to jedyne inicjatywy wzorowane na ruchu "socios" w ogóle. Programy nawiazzujacce bezpośrednio do
tej idei - również nazwa - pojawiały sie w ramach innych stotej idei - równiez nazwą - pojawialy się $\mathrm{w}$ ramach innych stotylko część działalności tych organizacji, dlatego nie zostały tylko czessc działalności tych organizaci,
uwzględnione w doborze przypadków. warzyszeń, materiały prasowe, social media), której celem było zebranie informacji o działalności poszczególnych stowarzyszeń oraz metodę wywiadu pogłębionego. Wywiady przeprowadzono z przedstawicielami „socios”, których można określić jako „liderów ruchu”. Były to osoby, po pierwsze, zaangażowane $\mathrm{w}$ powstanie organizacji, po drugie, pełniące $\mathrm{w}$ stowarzyszeniach oficjalne funkcje $(\mathrm{z}$ wyjątkiem jednego respondenta, który w momencie prac terenowych zaczynał swoją aktywność w organizacji), a po trzecie, angażujące się w ich „,codzienną" aktywność. Taki dobór próby opierał się na założeniu, że będą to osoby o najszerszej wiedzy z zakresu historii i działalności organizacji. Ze stowarzyszeniami skontaktowano się za pomocą adresów mailowych podanych na oficjalnych stronach internetowych. Respondenci dobierani byli przez osoby odpowiedzialne za kontakt ze strony poszczególnych "socios" zgodnie z logiką przedstawienia możliwie różnych perspektyw przez ich członków.

W badaniu wzięło udział łącznie siedmiu „liderów": trzech przedstawicieli "Socios" Stomilu Olsztyn oraz czterech "Socios" Górnika Zabrze. Wywiady w Zabrzu odbywały się jednak w małym pomieszczeniu wynajmowanym przez Stowarzyszenie, przed spotkaniem zarządu. W trakcie drugiego wywiadu w pokoju pojawiły się wszystkie osoby odpowiedzialne za decyzje $\mathrm{w}$ organizacji. $\mathrm{W}$ konsekwencji zmienił się on po czasie w wywiad grupowy, w którym wzięło udział łącznie czterech fanów (wypowiadał się również respondent, z którym przeprowadzono wcześniej wywiad pogłębiony). W rezultacie zatem zebrany materiał pochodzi z czterech wywiadów indywidualnych oraz jednego wywiadu grupowego. Badanie przeprowadzone zostało w okresie od października do grudnia 2016 roku.

Cytaty respondentów zostały wyróżnione od reszty tekstu, a tożsamość kibiców została zanonimizowana. Poniżej wypowiedzi podane jest jej źródło, które opisano w następujący sposób: nazwa klubu piłkarskiego oraz litera alfabetu odpowiadająca chronologii prowadzenia wywiadów z kibicami danego klubu. Wszystkie cytowane wypowiedzi pochodzą $\mathrm{z}$ badania własnego.

\section{Górnik Zabrze}

Stowarzyszenie "Socios Górnik" zostaje zawiązane we wrześniu 2014 roku³. Główną przyczyną powstania organizacji jest zła kondycja finansowa klubu. Jak wskazywali badani kibice, zadłużenie zewnętrzne klubu szacowano na 30 milionów złotych. Do tego dochodziła porównywalna kwota obligacji do spłaty (Górnik Zabrze, kibic A). Kluczowe dla pojawienia się reakcji ze strony kibiców w tym przypadku wydaje się jednak spiętrzenie różnych czynników powiązanych bezpośrednio ze złą sytuacją klubu. Jak wskazują kibice, takich zdarzeń było kilka:

Konkretnie też przez odejście prezesa Waśkiewicza. Waśkiewicz był utożsamiany jako osoba, która może temu klubowi pomóc (...). W momencie gdy on złożył rezygnację, no to u kibiców takie podłamanie lekkie. Plus odeszła Kompania Węglowa i to się wszystko nawarstwiło. To wszystko narastało. I stąd się wziął pomysł. Nawet nie stowarzyszenia, ale dobrowolnych

${ }^{3}$ Do KRS wpisane 5.11.2014: www.krs-online.com.pl/socios-gornik-krs-1478258.html (dostęp 14.03.2017 r.). 
składek. Ale, że te składki trzeba jakoś gdzieś wpłacać... (Górnik Zabrze, kibic C)

Kumulacja definiowanych przez kibiców jako nieprzychylne zdarzeń wywołała poczucie zagrożenia klubu i tym samym pierwsze spontaniczne reakcje. Jak zauważył cytowany fan Górnika, jeden z założycieli organizacji, te spontaniczne reakcje przerodziły się następnie w konkretne pomysły. Dopiero skonfrontowanie konkretnych pomysłów z rzeczywistością i obowiązującymi regułami instytucjonalnymi zrodziło pomysł formalnego ciała, odpowiedzialnego za zbiórkę i zarządzanie funduszami.

Główną rolę $\mathrm{w}$ tym procesie odegrał Internet jako przystępne i szybkie narzędzie komunikacji. Jak wskazywali członkowie "Socios Górnik”, to właśnie tam zrodziła się spontaniczna inicjatywa zbiórki funduszy, która po szerszej debacie zamieniła się $\mathrm{w}$ formalną organizację:

Ktoś tam na forum właśnie założył temat 20x12 miesięcy, że 20 zł miesięcznie razy 20000 kibiców Górnika przez rok, to zbierze się całkiem przyjemna kwota. I taka była idea. (Górnik Zabrze, kibic A)

Niezwykle ważny jest również fakt, że inicjatywa ta zawiązana była przez osoby, które wcześniej, oprócz interakcji na internetowym forum, się nie znały. Jest to dystynktywna cecha ruchu „socios" w porównaniu do istniejących do tej pory w Polsce formalnych i nieformalnych organizacji kibiców piłkarskich. Zarówno stowarzyszenia kibiców i animowane przez nie akcje społeczne/charytatywne/ patriotyczne (zob. Grodecki 2015), jak i protesty kibiców piłkarskich (zob. Chwedoruk 2015) oraz inicjatywy na rzecz odbudowy upadłych klubów (zob. Kossakowski 2017a) wychodziły od zorganizowanego już wtedy środowiska zaangażowanych kibiców. Innymi słowy, były efektem ewolucji relacji pomiędzy kibicami. „Socios" natomiast jest organizacją celową, skupiającą kibiców z różnych środowisk społecznych, których relacje kształtowane są przez stowarzyszenie:

De facto to myśmy się nie znali. Powiem szczerze, że na te 27 osób to ja znałem tutaj kolegę, bo jesteśmy z jednego bloku. A tak poza tym wszyscy byli dla siebie nieznajomi. (Górnik Zabrze, kibic A)

W tym sensie różnią się od tradycyjnych grup kibiców, których cechami charakterystycznymi są „zachowania trybalne, mocno unifikujące, oparte na silnej kontroli społecznej, starszeństwie i hierarchii, którą trudno określić jako demokratyczną bądź też opartą na umowie czy kontrakcie" (Antonowicz, Kossakowski, Szlendak 2011: 115). Fundamentem „socios" jest formalny statut, który zdecydowanie mocniej niż w przypadku tradycyjnych stowarzyszeń kibiców reguluje podstawowe relacje oraz zabezpiecza przed niepożądanymi względem celów grupy zachowaniami. W rezultacie zaufanie pomiędzy członkami stowarzyszenia oparte jest głównie na odpowiedniej kontroli prawnej:

Wszystkie przelewy, jakie wychodzą z konta, są też sygnowane przez trzy osoby, więc już, powiedzmy, na etapie statutu założyliśmy dużo takich bezpieczników, że nawet gdyby okazało się, że, powiedzmy, któryś z nas nie wiem - przeszedł na „ciemną stronę mocy" - i doszedł do wniosku, że te pieniądze z "Socios" on wykorzysta do celów niezgodnych ze statu- tem. No nie ma szans. Nie ma szans! Musiałby przekonać przynajmniej trzy osoby z zarządu. Trzy osoby z zarządu musiałyby się tej idei „Socios" sprzeniewierzyć, żeby jakiekolwiek pieniądze z tego wyciągnąć. (Górnik Zabrze, kibic A)

Bardziej formalny, w porównaniu do „tradycyjnych" stowarzyszeń kibiców, charakter relacji oraz geneza ruchu powodują również, że jest to organizacja o bardziej inkluzywnej naturze, oparta o zasady bliższe demokracji niż regułom starszeństwa. Jak opisuje jeden z członków zarządu stosunek organizacji do nowych osób:

na to spotkanie mogły przyjść, w każdej chwili mogły złożyć deklarację, mogą wystąpić o powiedzmy... Chęć uczestniczenia, bycia członkiem zarządu i poprowadzenia tego stowarzyszenia $\mathrm{w}$ inną stronę, my się przed nikim nie zamykamy. (Górnik Zabrze, kibic A)

Warto odnotować również świadomość odmienności interesów „Socios” od stowarzyszenia kibiców. Kibice wskazywali, że organizacja ma przede wszystkim być „ramieniem klubu”, a nie „ramieniem kibiców jak Torcida"4 (Górnik Zabrze, kibic C) oraz mobilizować biernych dotychczas fanów Górnika, w celu pozyskania większych środków na rzecz klubu:

My chcemy dotrzeć do osób niezależnych finansowo, które chcą wesprzeć klub nie tylko kupnem biletu, ale dodatkowymi środkami finansowymi. Do takich osób chcemy dotrzeć i to jest nasz cel działania. (Górnik Zabrze, kibic B)

"Torcida" - zwyczajowe określenie kibiców Górnika Zabrze, w tym również stowarzyszenia kibiców.
Inkluzywny charakter stowarzyszenia jest również widoczny $\mathrm{w}$ jego kontaktach $\mathrm{z}$ klubem. Jednym z głównych celów ruchu "socios" jest bowiem formalne współdecydowanie o działaniach swojego klubu. Pośrednictwo w gromadzeniu środków finansowych od kibiców klubu, czyli innymi słowy przekształcanie kapitału społecznego klubu w kapitał ekonomiczny, ma przyczynić się do legitymizacji „Socios Górnik” jako przedstawiciela kibiców w relacjach z klubem i tym samym jako realnego partnera dla władz klubu we współdecydowaniu o jego losach. Jak przedstawia statut organizacji:

W zamian chcemy współdecydować o klubie. Dzięki podnoszeniu kapitału zakładowego klubu staniemy się jego współudziałowcem, co da nam większą kontrolę nad tym, w jaki sposób wydawane są przez klub także i nasze środki. („Socios Górnik”, statut ${ }^{5}$.

Inicjatywy na rzecz zwiększenia inkluzywności głosu kibiców w działaniach władz klubu spotykają się jednak z oporem tego ostatniego. Władze klubu nie traktują „Socios” jako partnera, który może współdecydować o jego zarządzaniu. Kibice wskazywali, że klub chętnie przyjąłby zgromadzone na koncie stowarzyszenia środki finansowe, nie traktując jednak tego jako wykupienia głosu w zarządzie, ale jako darowiznę od fanów nie wiążącą się w żaden sposób $\mathrm{z}$ formalną redefinicją wzajemnych relacji:

No i tak naprawdę to jesteśmy takim kukułczym jajem, bo klub od nas chętnie by te pieniążki wziąl, bo mamy na koncie parę groszy ${ }^{6}$. Natomiast na takiej za-

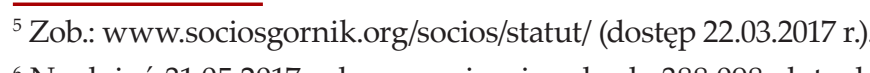
${ }^{6} \mathrm{Na}$ dzień 31.05.2017 roku organizacja zebrała 388098 złotych. Zob.: www.sociosgornik.org (dostęp 10.07.2017 r.) 
sadzie, że „przyjdźcie, zostawcie i nie pytajcie, co się z nimi dzieje". Mamy w statusie wyraźnie zapisane i taka jest też idea "Socios", i to też członkom „Socios" obiecaliśmy, że jeżeli przekażemy cokolwiek na Górnik, to z takim zaznaczeniem, że chcemy wiedzieć na co te środki zostaną spożytkowane. I to jest kłopot. (Górnik Zabrze, kibic A)

Brak dialogu z klubem i przez to brak legitymizacji organizacji ze strony instytucji, dla której dobra została powołana, wymusił na zabrzańskich „Socios” poszukiwanie alternatywnego środowiska, legitymizującego działalność Stowarzyszenia. Efektem tego są wysiłki skoncentrowane na wpisanie ruchu w globalną sieć zalegitymizowanych już przez innych instytucjonalnych aktorów (niektóre państwa UE, Rada Europy) organizacji, jak Supporters Direct.

Mieliśmy tu przedstawiciela Supporters Direct $\mathrm{w}$ tamtym roku (...). Nasz rzecznik miał do nich kontakt, opisał, że działamy, w jakim modelu i chcielibyśmy dowiedzieć się o możliwość przystąpienia (...) Porozmawialiśmy, dał nam kilka wskazówek (przedstawiciel SD - przyp. autor). (...) Zasugerował kilka stowarzyszeń, które mają podobne do nas problemy, albo wręcz odwrotnie - nie mają w ogóle problemów, tak jak my byśmy chcieli nie mieć (...). I od tego czasu, nie powiem, że to jest korespondencja ciaggła, ale od czasu do czasu my do nich, oni do nas (...). Nauka od kogoś, kto jest kilka kroków przed nami. (Górnik Zabrze, kibic C)

Wymiana informacji i doświadczeń ma miejsce również z drugim polskim stowarzyszeniem typu „socios", zorganizowanym przy klubie Stomil Olsztyn. W tym przypadku jednak relacje na linii klubkibice wyglądają zupełnie inaczej.

\section{Stomil Olsztyn}

Stowarzyszenie „Socios Stomil” powstaje na początku 2016 roku7 . Podobnie jak w przypadku Górnika jest odpowiedzią na niepewną sytuację ekonomiczną klubu. Świadomość responsywnego charakteru tego ruchu jest dobrze widoczna w wypowiedziach kibiców:

Gdyby ten klub normalnie funkcjonował, miał normalne struktury, był stabilny finansowo, no to wydaje mi się, jestem wręcz pewien, że to stowarzyszenie by nie powstało. Po prostu by nie było takiej potrzeby. No bo zawsze tam gdzie coś się dobrze dzieje, no to raczej nie ma inicjatyw oddolnych. Jak dobrze funkcjonuje, to po prostu kibice przychodzą na mecze, ewentualnie pomagają $\mathrm{w}$ jakichś tam akcjach, które klub chce rozpowszechnić, no to wtedy tak. (Stomil Olsztyn, kibic B)

Podobnie również jak w Zabrzu w Olsztynie nastąpiła kumulacja konkretnych zdarzeń, definiowanych przez kibiców jako negatywne. W przypadku Stomilu kibice podkreślali przede wszystkim złą sytuację finansową, infrastrukturalną oraz organizacyjną klubu. Podobieństwa w przypadku obu ruchów można dopatrzeć się również w roli Internetu. Informacje o inicjatywie i o pierwszych zebraniach grupy pojawiały się bowiem na stronie Stomilu na portalu społecznościowym Facebook. Kibice zrzeszeni w "Socios Stomil” przyznają zresztą otwarcie, że ich inicjatywa wzorowana jest na tej z Zabrza. Kontaktowano się z przedstawicielami „Socios Górnik”, aby skorzystać na ich do- świadczeniu organizacyjnym i uzyskać informacje na temat funkcjonowania tego typu organizacji (Stomil Olsztyn, kibic B).

Wymiana doświadczeń przyczyniła się również do redefinicji inkluzywności w relacjach klub-kibice. Przede wszystkim, przez doświadczenia „Socios" w Zabrzu - jak wskazują kibice w Olsztynie - w zamian za swoją pomoc nie planowali uzyskać formalnego głosu w zarządzaniu klubem. Choć na oficjalnej stronie internetowej organizacji, w zakładce „,cele stowarzyszenia”, można znaleźć informację o misji „wprowadzenia systemu zarządzania klubem, w którym kibice mają wpływ na jego działalność i funkcjonowanie" (Socios Stomil ${ }^{8}$ ); ma odbywać się to przez „współpracę i integrację" z klubem. Jak zaznaczył jeden z działaczy ruchu:

Chcieliśmy, może nie mieć konkretny wpływ na działanie klubu, bo to było praktycznie niemożliwe. Przykład Górnika pokazuje (...). Widzieliśmy, że nie będziemy mieli dużego wpływu, ale będziemy mogli próbować coś robić i próbować coś zmienić w jakiś sposób - współpracować, bardziej się integrować. (Stomil Olsztyn, kibic A)

Podobnie jak w Zabrzu ruch „Socios” został zainicjowany przez osoby niewywodzace się bezpośrednio ze środowiska zorganizowanych kibiców. W przeciwieństwie jednak do Górnika został przez nie zaakceptowany. Również nieco inaczej wyglądała sytuacja na polu formalnych przedstawicielstw fanów - w Zabrzu bowiem istniało już stowarzyszenie kibiców. W Olsztynie natomiast ${ }^{8}$ Zob.: www.sociosstomil.pl/o-nas/cele-stowarzyszenia/ (do-
stęp: 20.03.2017 r.). takie stowarzyszenie właśnie upadało z powodu nieścisłości finansowych. Jego nienajlepsza prasa przyczyniła się do początkowej nieufności ze strony środowiska kibiców Stomilu względem nowej organizacji. Jak wskazywał jeden z nowych (w momencie prowadzenia badań terenowych) członków "Socios":

No z dystansem, tak żeby nie zaliczyć jakiejś draki, wejść do jakiejś ekipy złodziei czy coś, bo ja tego nie chcę, kurwa. Chciałem zobaczyć, jak oni działają ogólnie, czy naprawdę działają na dobro klubu, czy, kurwa, tylko dla siebie, dla swojego interesu (...). Z początku to nie wierzyłem $\mathrm{w}$ to, bo już było parę stowarzyszeń, robili, kurwa, co chcieli. A tutaj widać, że w spotkali się chłopaki z innego klimatu, nie z młyna, tylko z trybun normalnie i mają inne podejście do tego wszystkiego. (Stomil Olsztyn, kibic C)

W konsekwencji jednak, i w przeciwieństwie do Zabrza, pewne zaufanie ze strony istniejącego już, zorganizowanego środowiska kibiców olsztyńskiego klubu udało się wypracować.

Relacje oparte na zaufaniu zaczęły również być widoczne między aktywnymi członkami organizacji. Trzeba podkreślić, że $\mathrm{w}$ momencie prowadzenia badań w Olsztynie (październik 2016) Stowarzyszenie "Socios Stomil" istniało zaledwie od siedmiu miesięcy. Fani wskazywali, że na początku ustalono przede wszystkim formalne reguły wzajemnej kontroli osób odpowiedzialnych za kwestie finansowe (Stomil Olsztyn, kibic A). Wspólne działania na rzecz klubu szybko jednak zbudowały zaufanie i pierwsze więzi między kibicami: 
Jeśli chodzi o Socios, to tutaj też wydaje mi się, załatwiamy różne sprawy, no to rozmawiamy między sobą, jak to wszystko zorganizować, wiadomo też rozmawiamy o Stomilu. No i stąd jakby biorą się te wszystkie relacje. Tak więc no tutaj przez to, że działamy w jednym kręgu, no to też trudno, żeby nie powstawały więzi między nami. Wiadomo, człowiek tam nie zna tę osobę, ale później się jakby tam pozna. (...) na początku było na zasadzie „,raczej”, no ale później pojawiły się kolejne akcje, zobaczyłem, że jakby to $\mathrm{w}$ dobrym kierunku idzie (...) z tego tytułu to mi się jakoś tak spodobało i te zaufanie z tego jakby się wzięło. (Stomil Olsztyn, kibic B)

Równie dynamicznie prezentują się relacje „Socios" z klubem. Początkowym celem ruchu była głównie pomoc finansowa. Sytuacja ekonomiczna klubu, wraz z wejściem dużego sponsora, uległa jednak z czasem poprawie. W związku z tym ewoluowały również cele Stowarzyszenia, które skoncentrowały się na realizacji zadań marketingowych i PR-owych klubu (praca na rzecz wizerunku klubu, pozyskiwanie partnerów biznesowych itp.):

stowarzyszenie powstawało, to wtedy była zła sytuacja finansowa Stomilu i jakby główny wątek był chęć pomocy finansowej (...) teraz, jak ta stabilizacja klubu się uporządkowała troszeczkę (...) to te nasze działania polegają bardziej na promocji klubu, polepszaniu wizerunku, pomocy w różnych rodzaju działaniach i różnych przedsięwzięciach. (...) to wszystko my robimy dla dobra klubu, klub to widzi, jest tutaj jakby z nas - wydaje mi się - zadowolony, dlatego wydaje mi się wszystko fajnie funkcjonuje. (Stomil Olsztyn, kibic B)
Współpraca z klubem przyczyniła się również do efektywności Stowarzyszenia w wypracowaniu inkluzywnego modelu we wzajemnych relacjach. W grudniu 2016 roku została powołana fundacja „Akademia Sportu Stomil Olsztyn" odpowiedzialna za szkolenie młodzieży. Co oczywiste, Akademia ma ściśle współpracować z klubem oraz, co mniej oczywiste, z „Socios”. Jeden z członków Stowarzyszenia został bowiem koordynatorem do spraw marketingu tych trzech podmiotów. W przyszłości natomiast związek klubu z „Socios” ma zostać jeszcze bardziej sformalizowany, bowiem jeden $\mathrm{z}$ kibiców ma zasiadać $\mathrm{w}$ zarządzie powstającej fundacji (Stomil Olsztyn, kibic A).

\section{Polski ruch „socios"}

Analizując ruchy sprzeciwu kibiców piłkarskich w Europie, Dino Numerato (2015:133 [tłum. własne]) zauważył, że mimo ich "racjonalnych pobudek, są one najczęściej wyrażane w zrytualizowany i silnie emocjonalny sposób”. Polski ruch „socios” i generalnie organizacje typu Supporters Trust są inną, a na polskim gruncie zupełnie nową formą kontestacji rzeczywistości. Można je opisać w kategoriach blumerowskiego społecznego ruchu reformatorskiego (zob. Blumer 1951) - starają się wpłynąć na zmianę w konkretnym fragmencie rzeczywistości, wykorzystując do tego zalegitymizowane instytucje (forma stowarzyszenia, składki, zebrania itp.) oraz, przynajmniej w przypadku „Socios Górnik", świadomie kierują swoje działania do przedstawicieli klasy średniej („My chcemy dotrzeć do osób niezależnych finansowo" - Górnik Zabrze, kibic B).

Podobnie jednak jak tradycyjne, kibicowskie ruchy sprzeciwu oraz angielskie „trusty” polski ruch „socios" ma responsywny charakter. Zarówno w przypadku Górnika Zabrze, jak i Stomilu Olsztyn stowarzyszenia tego typu powstały w wyniku nawarstwienia się problemów związanych z niestabilną sytuacją finansową klubu. Badania kibiców FC Liverpool Petera Millwarda (2012) oraz fanów Newcastle United Jamie Clelanda i Kevina Dixona (2015) wskazywały, że główną motywacją kibiców do działań na rzecz klubu w niestabilnej sytuacji ekonomicznej jest zagrożenie poczucia „własności kulturowej" klubu. Ta hipoteza zdaje się również potwierdzać w kontekście polskich „socios”. Członkowie tych organizacji, zarówno z Zabrza, jak i Olsztyna, zgodnie potwierdzali znaczenie klubu dla ich tożsamości:

To jest ta motywacja, że ten klub jest $\mathrm{w}$ takiej, a nie innej sytuacji, że chcemy temu klubowi pomóc, chcemy w jakiś sposób się z tym klubem utożsamiać. (Górnik Zabrze, kibic A)

Klub jest dla mnie bardzo ważny, wręcz nawet stadion to jest jak drugi dom, Stomil to jest jakby ta miłość nawet wręcz, w tych kategoriach. Dlatego tutaj właśnie mi się stąd wzięła się potrzeba coś pomocy. (Stomil Olsztyn, kibic B)

To, co kluczowe dla obu ruchów, to fakt, że zostały zainspirowane i w dużej mierze są współtworzone przez fanów niezwiązanych ze zorganizowanym środowiskiem kibiców piłkarskich obu klubów. "Nowi aktywiści", jak można by określić tę kategorię kibiców, różnią się również cechami społecznymi od kibiców „industrialnych”, tworzących do tej pory różne formy organizacji kibicowskich. Analiza stowarzyszenia "Spirit of Shankly” Millwarda
(2012: 4) wskazywała, że choć ruch ten w większości tworzony był przez tradycyjnych kibiców, to osoby odpowiedzialne za zarządzanie organizacją już do tej kategorii nie należały, rekrutując się głównie z klasy kreatywnej. Bez ilościowego badania członków ruchu "socios" w Polsce trudno oczywiście określić całościowy profil demograficzny i typologiczny tej organizacji. Analizując natomiast zawody przedstawicieli zarządów polskich "socios”, można zauważyć, że nie tworzą oni wspólnego portretu klasowego (górnicy, pracownicy handlu, agenci nieruchomości oraz przedsiębiorcy ${ }^{9}$ ). Wyróżniającą cechą demograficzną jest natomiast etap cyklu życia, $\mathrm{w}$ jakim się znajdują. Jak podkreślił jeden z członków zarządu „Socios Stomil”:

Raz, że my mamy środki, mamy lepiej życie poukładane, lepiej w głowach poukładane, lepiej potrafimy sobie niektóre rzeczy zorganizować (...). Myślę, że te osoby, które są w młynie, też z czasem przejdą, że tak powiem, na inny tryb kibicowania - ze względu na wiek, ze względu na odpowiedzialność. (Stomil Olsztyn, kibic B)

Można zaryzykować zatem hipotezę, że polski ruch "socios" jest ruchem nie tyle innej klasy społecznej, co raczej nowej kategorii widzów - „nowych aktywistów" - która w dotychczasowych (wywodzących się ze zorganizowanego ruchu kibiców) formach relacji kibic-klub nie odnajdywała dla siebie miejsca. „Nowym aktywistom” jako osobom, które uzyskały odpowiedni status społeczny i finansowy

${ }^{9}$ Informacje o zawodach członków zarządów pochodzą z wywiadów oraz oficjalnych stron organizacji: http://sociosstomil. pl/o-nas//udzie-socios/; http://sociosgornik.org/socios/ludzie-
-socios/(dostęp 21.03.17 r.). 
w ramach obowiązującego porządku społecznego, sama idea ruchu „socios” czy Supporters Trusts jako wykorzystującego zalegitimizowane już narzędzia sprzeciwu musiała wydać się dużo atrakcyjniejszą niż kibicowska - w dużej mierze młodzieżowa rywalizacja. „Nowi aktywiści” przez organizacje „socios" wprowadzili zatem nowy rodzaj ekspresji relacji z klubem.

W związku z tym nasuwa się również pytanie o miejsce tej nowej formy relacji w szerszych przemianach społecznych. Brytyjscy badacze wskazywali (zob. Cleland 2010; Cleland, Dixon 2015), że nowa kategoria „,aktywnych” fanów była efektem zmian struktury tamtejszego społeczeństwa, w której tradycyjne zawody robotnicze zastępowano usługami. „Aktywni” fani wprowadzili nowe, prosumenckie formy przywiązania do klubu - w tym „trusty" jako demokratyczne narzędzie sprzeciwu.

Podobna zmiana struktury społecznej ma miejsce obecnie w Polsce. Jak wskazują jednak badania, nie przełożyła się ona jeszcze na obywatelskie umiejętności Polaków. Komentując wyniki Diagnozy Społecznej z 2013 roku (potwierdzonego również przez wyniki tego badania w 2015 roku), Antoni Sułek (2013: 284) zauważył, że „Polacy nie umieją się organizować i skutecznie działać wspólnie (...). Nie umieją, bo się tego nie nauczyli z ich ubogiego doświadczenia. Nie umieja, bo nie działaja, a nie działają, bo nie umieją jest to błędne koło działań dla społeczności".

Wydaje się, że w przypadku polskich „socios" nauce demokracji (umiejętności wykorzystania reguł i narzędzi demokratycznych do realizacji wspólnych celów) sprzyjały dwa czynniki. Po pierwsze, opierając się na demografii liderów organizacji „socios" - czyli osób o stabilnej sytuacji życiowejmożna wskazać na tak zwane podejście ekonomiczne w wyjaśnianiu poziomu zaangażowania obywatelskiego (Curtis, Baer, Grabb 2001). W tym ujęciu jakość społeczeństwa obywatelskiego jest ściśle zależna od poziomu gospodarczego - im korzystniejsza sytuacja ekonomiczna (również na poziomie indywidualnym), tym ludzie chętniej angażują się w działania społeczne. Po drugie, taka forma instytucjonalizacji ruchu kibicowskiego wynika z pewnego napięcia między tradycją klubów piłkarskich a logiką rynku. W tej interpretacji to „bezwzględne” reguły wolnego rynku wymuszają szybszą „naukę demokracji". Piłka nożna jest sferą życia społecznego, w której zasady rynku były długo nieobecne, przez co funkcjonowała ona według swoich własnych reguł instytucjonalnych. Kiedy natomiast wolny rynek wkroczył do polskiego futbolu, gwattowne zmiany systemowe zweryfikowały te kluby, które nie potrafily się szybko do nich dostosować W tym sensie ruch socios jako ruch "reformatorski” jest nie tylko pewną formą sprzeciwu wobec złej kondycji klubów, ale również pewną oddolną, pośrednią (bowiem prowadzoną przez kibiców, jako aktorów zewnętrznych wobec klubu) próbą adaptacji klubów do nowych reguł.

Kontynuując ten wątek, warto zaznaczyć, że w obu analizowanych przypadkach „nauka demokracji” nie odbywa się wyłącznie przez działania. Również przez kontakty z innymi tego typu organizacjami (zarówno między sobą, jak i w przypadku Górnika z Supporters Direct) oraz, przede wszystkim, przez uczenie się na błędach istniejących już lub istniejących wcześniej organizacji kibicowskich:
No bo tam były poruszane tematy (na zebraniu założycielskim - przyp. MG), które były kiedyś, których chcemy unikać, żeby nie było jak kiedyś, bo już od początku były takie założenia, żeby nie popełniać tych samych błędów, co tamci poprzednicy (istniejące wcześniej stowarzyszenie kibiców - przyp. MG). (Stomil Olsztyn, kibic A)

Trzeba podkreślić jednak po raz kolejny, że powyższe wnioski dotyczą głównie liderów omawianego ruchu. Bowiem w obu omawianych przypadkach w „codzienną” działalność stowarzyszeń - jak szacują sami kibice - angażuje się tylko kilkanaście osób. Aktywność pozostałej części członków (,,Socios Stomil” - łącznie 127 członków oraz 9 firm, „,Socios" Górnik - 1079 osób - stan na 23.03.2017 roku) sprowadza się głównie do opłacania składek. W takim wypadku bezpośrednie relacje nawiązywane są jedynie przez aktywnych działaczy. Tym samym tylko w obrębie tej grupy można mówić o budowaniu zaufania i kapitału społecznego typu bridging (Putnam 2008). Zaangażowanie pozostałej części członków, sprowadzające się do opłacania składek, można scharakteryzować słowami Putnama (2008: 89), oryginalnie opisujaccymi tertiary organizations, który skonstatował, że generalnie członkowie tych organizacji „,są przywiązani do wspólnych symboli (...), wspólnych ideałów, ale nie do siebie nawzajem".

Na pierwszy rzut oka wydaje się również, że w przypadku dwóch analizowanych, polskich ruchów „socios” potwierdza się wniosek, że działania na rzecz zwiększenia inkluzwyności tego typu organizacji są skuteczniejsze w mniejszych klubach, pozostających bardziej lokalnymi markami (Martin 2007). Górnik Zabrze to jeden z najbardziej utytu- łowanych polskich klubów piłkarskich (59 sezonów w Ekstraklasie i 14 tytułów mistrzowskich), podczas gdy Stomil to klub raczej z regionalnymi tradycjami, bez dużych sukcesów (8 sezonów w najwyższej klasie rozgrywkowej). Przyglądając się temu problemowi bliżej, można dostrzec jednak inne przyczyny tego zjawiska.

W przypadku „Socios Górnik” inkluzywność definiowana jest przez zinstytucjonalizowaną już na Wyspach (Lomax 2000) ideę wsparcia finansowego czy wykupienia udziału w klubie za formalne prawo głosu w spółce. W Olsztynie natomiast tamtejsze "Socios" zredefiniowało swoją misję względem klubu (wskutek pojawienia się sponsora, który ustabilizował nieco sytuację finansową klubu, oraz również dzięki doświadczeniom z Zabrza - przyp. MG), zajmując się działalnością marketingową, nieobecną oficjalnie w klubie z powodów niskiego budżetu. Jak pokazują relacje obu organizacji z klubami, strategia działania na rzecz inkluzywności nastawiona na kontrolę klubu ze strony kibiców (Zabrze) wzbudza nieufność wśród jego włodarzy. Natomiast podejście, które można tu nazwać „partnerskim" (Olsztyn), przyczyniło się w konsekwencji do większej inkluzywności w relacjach Stowarzyszenia z klubem, czego doskonałą ilustracją jest powierzenie funkcji koordynatora do spraw marketingu Stomilu, Akademii Piłkarskiej oraz "Socios” przedstawicielowi tej ostatniej organizacji. Podkreślić należy jednak, że w momencie prowadzenia analiz (połowa 2017 roku) żadnej z organizacji nie udało się uzyskać formalnego głosu w zarządzie klubu. "Socios Stomil" współpracowali z klubem, tworząc nowe struktury, ale nie udało im się zredefiniować tych istniejących. 
Mimo wszystko wydaje się jednak, że na polskim gruncie efektywniejsza jest strategia działania na rzecz „partnerskiej” inkluzywności w relacjach klub-kibice. Zastrzec należy jednak, że istnieją pewne lokalne czynniki, które mogły w dużym stopniu przyczynić się do takich rezultatów. W Zabrzu przedstawiciele klubu oraz kibiców zarzucają tamtejszym „Socios", że są organizacją utworzoną, aby przywrócić władzę jednemu z poprzednich prezesów Górnika, zwolnionemu oficjalnie za złe wyniki finansowe klubu. Wśród „Socios” natomiast pojawiają się głosy zwątpienia $\mathrm{w}$ transparentność będącego własnością miasta klubu, który nie chce podpisać umowy o współpracy ze Stowarzyszeniem, przez co zgromadzone środki ciągle pozostają na koncie "Socios”. Rozstrzygnięcie tego sporu leży poza kompetencjami przedstawianej analizy. Podkreślić natomiast należy, że w tym kontekście to polityczny charakter sporu, a nie „wolnorynkowa nieosiągalność" dla pozakorporacyjnych aktorów leży u podstaw niepowodzenia współpracy „Socios Górnik" z klubem.

Z drugiej strony, co podkreślali również sami kibice (Stomil Olsztyn, kibic A; Górnik Zabrze, kibic C), wpływ na większą inkluzywność klubu w relacji z ruchem „socios” może mieć podłoże finansowe. Górnik Zabrze utrzymywany jest przez miasto, które regularnie dofinansowuje klub dużymi kwotami. Tylko na początku 2017 roku miasto dofinansowało klub kwotą ponad 32 milionów złotych (Musioł 2017). W Olsztynie natomiast miejskie władze przekazały „Stomilowi 200 tys. złotych w ramach zwycięstwa w konkursie Promocja Miasta Olsztyna poprzez sport podczas rozgrywek w piłce nożnej mężczyzn: I ligi i grup młodzieżowych" (Sport Warmii i Mazur
2016). W tym sensie zatem rynkowa rzeczywistość może regulować przychylność klubów wobec kibicowskiego postulatu zwiększenia inkluzywności i tym samym efektywność organizacji kibicowskich w lobbowaniu za takimi relacjami.

Nie ulega jednak wątpliwości, że celem obu Stowarzyszeń jest działanie na rzecz klubu (dla przykładu "Socios Górnik" przeznaczyli 100 tys. zł. na premię dla piłkarzy za wywalczenie w sezonie 2016/17 awansu do Ekstraklasy). W tym znaczeniu „socios” stanowią formalny kapitał społeczny klubu (zob. Sahaj 2011). W gruncie rzeczy bowiem klub piłkarski czerpie korzyści z sieci powiązań ze swoimi kibicami i sieci powiązań swoich kibiców. Po pierwsze finansowe, gdyż sieci mobilizowane są często do zbiórek finansowych oraz, dzięki często wolontariackiej pracy kibiców, do obniżania lub zastępowania kosztów w niektórych sferach działalności klubu (działania marketingowe „Socios Stomil”). Po drugie wizerunkowe, gdzie obywatelskie zaangażowanie buduje wiarygodność instytucji.

\section{Konkluzje}

Dotychczasowe formy zaangażowania kibiców piłkarskich były głównie efektem spontanicznej ewolucji więzi między kibicami. Analizowany tu ruch „socios" opiera się natomiast na więziach celowych, powstałych w wyniku formalnego zaangażowania $\mathrm{w}$ klub piłkarski. W przeciwieństwie do spontanicznych form kapitału społecznego obecnych dotychczas na trybunach nie jest on efektem ewolucji więzi pomiędzy kibicami - utrwalania norm wzajemności, odpowiednich sankcji i w konsekwencji powstawania zaufania $\mathrm{w}$ danym środo- wisku (Grodecki 2017) - a, jak pokazuje badanie, efektem mobilizacji „nowych aktywistów” kibicowskich w obliczu kryzysu poczucia „własności kulturowej" klubu.

John Williams (2012: 439) zauważył, że kluczowy dla tego typu ruchu kibicowskiego jest moment powrotu do poczucia normalności. Badanie przeprowadzone w Wielkiej Brytanii na zlecenie działającego tam Supporters Direct pokazało, jak komentował były prezes tej organizacji, Tom Hall, „że w miejscach, w których fani maja udziały, kibice czują, że przyszłość klubu spoczywa w ich własnych rękach i że nie są bezsilni jak wcześniej. Zapewnia to, że relacje pomiędzy zarządem a kibicami - nawet tymi nienależącymi do organizacji - cechuje zaufanie, którego trudno doświadczyć gdzie indziej w świecie futbolu" (Keoghan 2016: 214).

\section{Bibliografia}

Antonowicz Dominik, Kossakowski Radosław, Szlendak Tomasz (2011) Ostatni bastion antykonsumeryzmu? Kibice industrialni w dobie komercjalizacji sportu. „Studia Socjologiczne”, t. 202, s. 113-139.

Antonowicz Dominik, Kossakowski Radosław, Szlendak Tomasz (2015) Aborygeni i konsumenci. O kibicowskiej wspólnocie, komercjalizacji futbolu i stadionowym apartheidzie. Warszawa: Wydawnictwo IFiS PAN.

Blumer Herbert (1951) Social Movements [w:] Alfred McClung Lee, ed., New Outline of the Principles of Sociology. New York: Barnes \& Noble, s. 199-221.

Brown Adam (2007)"Not For Sale"? The Destruction and Reformation of Football Communities in the Glazer Takeover of Manchester United. ,,Soccer and Society", vol. 8, no. 4, s. 614-635.
W Polsce jest jeszcze za wcześnie, aby stawiać tak odważne wnioski jak Hall (abstrahując już od braku odpowiednich danych), bowiem ruch ten jest zbyt świeży oraz (przynajmniej na razie) obecny w dużo mniejszej skali niż na Wyspach. Trudno mówić także o poczuciu powrotu do normalności, gdyż opisywane tu stowarzyszenia są raczej na początku swojej drogi. Zgodnie jednak ze słowami Williamsa, przyszłość pokaże, czy polski ruch „socios” jest efektywną formą walki o większą inkluzywność w relacjach klub-kibice oraz, jeżeli okaże się skuteczna, jak kibice wywiążą się ze swojej nowej roli.

\section{Podziękowania}

Dziękuję recenzentom za ich zaangażowaną pracę oraz życzliwość, dzięki którym artykuł stał się po prostu lepszy. 
Cleland Jamie A. (2010) From Passive to Active: The Changing Relationship between Supporters and Football Clubs. „Soccer \& Society", vol. 11, no. 5, s. 537-552.

Cleland Jamie A., Dixon Kevin (2015)'Black and Whiters': The Relative Powerlessness of 'Active' Supporter Organization Mobility at English Premier League Football Clubs. „Soccer \& Society” vol. 16, no. 4, s. 540-554.

Curtis James, Baer Douglas, Grabb Edward (2001) Nations of Joiners: Explaining Voluntary Association Membership in Democratic Societies. „American Sociological Review”, vol. 66, no. 6, s. 783-805.

Dudała Jerzy (2004) Fani-chuligani: rzecz o polskich kibolach: studium socjologiczne. Warszawa: Wydawnictwo Akademickie „Żak”.

García Borja, Welford Joe (2015) Supporters and Football Governance, From Customers to Stakeholders: A Literature Review and Agenda for Research. „Sport Management Review”, vol. 18, no. $4, \mathrm{~s} 517-528$.

Giulianotti Richard (2002) Supporters, Followers, Fans and Flaneurs: A Taxonomy of Spectator Identities in Football. „Journal of Sport and Social Issues", vol. 26, no. 1, s. 25-46.

Grodecki Mateusz (2015) Trzecia strona trybun. Działalność stowarzyszeń kibiców pitkarskich w Polsce. „Miscellanea Anthropologica et Sociologica", t. 16, nr 4, s. 100-115.

Grodecki Mateusz (2017) Building Social Capital: Polish Football Supporters through the Lens of James Coleman's Conception. „International Review for the Sociology of Sport”. Dostępny w Internecie: http://journals.sagepub.com/doi/ abs/10.1177/1012690217728728; [dostęp 22 września 2017 r.].

Guschwan Matthew (2007) Riot in the Curve: Soccer Fans in Twenty-first Century Italy. „Soccer \& Society”, vol. 8, no. 2-3, s. 250-266.

Kennedy Peter (2012) Supporters Direct and Supporters' Governance of Football: A Model for Europe? „Soccer \& Society”, vol. 13, no. 3, s. 409-425.

Keoghan Jim (2016) Futbolowa rewolucja. Kibice wkraczaja do gry. Przełożył Janusz Zołociński. Warszawa: Wydawnictwo Magnus.
Kossakowski Radosław (2017a) From the Bottom to the Premiership: The Significance of Supporters' Movement in the Governance of Football Clubs in Poland [w:] Borja Garcia, Jinming Zheng, eds, Football and Supporter Activism in Europe. Whose Game Is It? Basingstoke: Palgrave Macmillan, s. 233-256.

Kossakowski Radosław (2017b) Od chuliganów do aktywistów? Polscy kibice i zmiana spoteczna. Kraków: UNIVERSITAS.

Lomax Brian (2000) Democracy and Fandom: Developing a Supporters' Trust at Northampton Town FC. ",Soccer \& Society", vol. 1, no. 1 , s. 79-87.

Martin Paul (2007) Football, Community and Cooperation: A Critical Analysis of Supporter Trusts in England. „Soccer \& Society”, vol. 8, no. 4, s. 636-653.

Millward Peter (2012) Reclaiming the Kop? Analysing Liverpool Supporters' 21st Century Mobilizations. „Sociology”, vol. 46, no. 4, s. 633-648.

Millward Peter, Poulton George (2014) Football Fandom, Mobilization and Herbert Blumer: A Social Movement Analysis of FC United of Manchester. „Sociology of Sport Journal”, vol. 31, no. 1. s. 1-22.

Musioł Rafał (2017) Górnik Zabrze dostanie 32 miliony złotych Wypłaci je bank, a miasto odda mu z nadwyżka. „Dziennik Zachodni". Dostepny w Internecie: «www.dziennikzachodni.pl/ sport/a/gornik-zabrze-dostanie-32-miliony-zlotych-wyplacije-bank-a-miasto-odda-mu-z-nadwyzka,11789384/s [dostęp 22 marca 2017 r.].

Nash Rex (2000) Contestation in Modern English Professional Football: The Independent Supporters Association Movement. „International Review for the Sociology of Sport", vol. 35, no. 4, s. $465-486$.

Nosal Przemysław (2015) Spoteczne ujęcie sportu. (Trudne) definiowanie zjawiska i jego dyskurs. „Przegląd Socjologii Jakościowej", t. 11, nr 2, s. 16-38.

Numerato Dino (2015)'Who Says No to Modern Football?' Italian Supporters, Reflexivity, and Neoliberalism. ,Journal of Sport \& Social Issues", vol. 39, no. 2, s. 120-138
Putnam Robert (2008) Samotna gra w kreggle: upadek i odrodzenie wspólnot lokalnych w Stanach Zjednoczonych. Przyłożyli Przemysław Sadura i Sebastian Szymański Warszawa: Wydawnictwa Akademickie i Profesionalne.

Sahaj Tomasz (2011) Fani sportowi jako kapitat spoteczny [w:] Sahaj Tomasz, red., Od fana do chuligana: kibicowanie w sporcie wspótczesnym. Poznań: Akademia Wychowania Fizycznego im. Eugeniusza Piaseckiego, s. 53-70.

Sport Warmii i Mazur (2016) Stomil Olsztyn ma nowego sponsora! Dostępny w Internecie: «sport.wm.pl/350689,Stomil-Olsztyn-ma-nowego-sponsora.html\#ixzz4c3BB9joDy [dostęp 22 marca 2017 r.].

Sułek Antoni (2013) Doświadczenie, działania dla społeczności i kompetencje obywatelskie. Diagnoza Spoteczna 2013, s. 275-284.
Testa Alberto, Armstrong Gary (2010) Football, Fascism and Fandom: The Ultras of Italian Football. London: A and C Black Publishers Ltd.

Touraine Alain (1981) The Voice and the Eye. An Analysis of Social Movements. Cambridge: Cambridge University Press.

Williams John (2006)'Protect Me from What I Want': Football Fandom, Celebrity Cultures and 'New' Football in England. "Soccer \& Society", vol. 7, no. 1, s. 96-114.

Williams John (2007) Rethinking Sports Fandom: The Case of European Soccer. „Leisure Studies", vol. 26, no. 2, s. 127-146.

Williams John (2012)Walking Alone Together the Liverpool Way: Fan Culture and 'Clueless' Yanks'. "Soccer \& Society", vol. 13, no. 3, s. $426-442$.

\section{Cytowanie}

Grodecki Mateusz (2018) Nowi aktywiści. Polski ruch „socios" jako nowa forma relacji kibiców z klubem. „Przegląd Socjologii Jakościowej", t. 14, nr 2, s. 30-49 [dostęp dzień, miesiąc, rok]. Dostępny w Internecie: ‘www.przegladsocjologiijakosciowej.org. DOI: http://dx.doi.org/10.18778/1733-8069.14.2.02.

\section{New Activists. Polish “Socios” Movement as a New Form of Relation with Football Clubs}

Abstract: The paper is focused on the Polish "socios" movement which is a relatively new form of institutionalized football fandom in Poland. The presented analysis aims to: 1) investigate sociogenesis of the movement in Poland, 2) describe relations among fans within organizations, and 3) explore relations between "socios" and their football clubs. The study is based on two case studies-"Socios Górnik" Zabrze and "Socios Stomil" Olsztyn which are only two existing "socios" organizations in Poland. The results show that both "socios" organizations emerged as a response to serious and long-lasting financial problems of their clubs which threatened the supporters' "sense of cultural ownership" of the club. What is more, both „socios" organizations were established by a new category of football supporters (described in the paper as "new activists"). The study also shows that these two organizations differ in their relations with the clubs-the relation between Stomil Olsztyn and their "Socios" can be described as an inclusive one, while Górnik Zabrze authorities have exclusive approach to "their" "Socios". The main reasons of this difference can be found in a) different definition of inclusiveness in the club-supporters relations, b) politicization of the club authorities, and c) in different level of the financial dependence of the club from the municipal authorities.

Keywords: sociology of sport, football supporters, football fandom, social capital, supporters activism 